\title{
Ruy Barbosa en el Centenario de 1916: apogeo de la confraternidad entre Brasil y Argentina ${ }^{1}$
}

\author{
Pablo Ortemberg**
}

Recibido el 6 de enero de 2018; aceptado el 15 de febrero de 2018

\begin{abstract}
This paper analyzes the political, social and cultural implications of the special embassy sent to Buenos Aires by the Brazilian government in honor of Argentine's celebrations of its Centennial of Independence in 1916 in the context of the Great War. This endeavor was led by the prestigious Brazilian jurist, senator and Conselheiro (counselor) Ruy Barbosa and demonstrates the climax of a period of rapprochement between the two countries initiated by president Roque Sáenz Peña's official missions in 1910. The analysis traces Barbosa's profile being both ambassador and jurist during his month-long stay at Buenos Aires focusing on images and identities presented in his speeches, public rituals of political and cultural approximation, achievements and tensions thereafter, as well as the impact Barbosa had in media and public sectors by the study of the many letters he received. The peak of this diplomatic rapprochement between Argentina and Brazil was prompted by "Europe's demise into barbarism" as all rights and conventions were overturned.

Key words: Ruy Barbosa, 1916 Centennial, Argentina-Brazil relationships, European War.

1 Esta investigación fue realizada gracias a los aportes del subsidio del Instituto Panamericano de Geografía e Historia (IPGH) en el marco del proyecto HIST012016, "Panamericanismo, latinoamericanismo y nacionalismos. Debates, encrucijadas y festejos identitarios, 18891928 ".

* cONICET-CEHP/EPYG/UNSAM, correo electrónico: pabloortembrg@gmail.com
\end{abstract}




\section{RESUMEN}

Este trabajo analiza las implicancias políticas, sociales y culturales de la embajada extraordinaria enviada por el gobierno del Brasil para homenajear a la nación argentina en los festejos del Centenario de la Independencia de 1916, en el contexto internacional de la Gran Guerra. La misión fue presidida por el mundialmente famoso jurista, senador y Conselheiro Ruy Barbosa y demuestra que coronó un ciclo de acercamiento político entre los dos países iniciado por la presidencia de Roque Sáenz Peña en 1910 a partir de misiones oficiales. Se estudia el perfil del "jurista embajador" en el marco de su estancia de un mes en Buenos Aires, las imágenes e identidades que actualizaron sus discursos, los rituales de acercamiento político y cultural puestos en escena, los éxitos y tensiones suscitadas, así como el impacto que causó su figura en sectores medios y populares a través de las numerosas cartas que recibió. Este momento culminante del ciclo de acercamiento entre Argentina y Brasil, vehiculizado por el célebre internacionalista, fue propiciado por el "hundimiento de Europa en la barbarie", cuando todos los derechos y convenciones quedaban avasallados.

Palabras clave: Ruy Barbosa, Centenario 1916, Relaciones argentino-brasileras; Guerra europea.

\section{INTRODUCCIÓN}

耳n julio de 1916, el presidente Venceslau Brás (1914-1918) nombró Embajador Extraordinario y Ministro Plenipotenciario al mundialmente prestigioso senador e internacionalista Ruy Barbosa para representar a Brasil en los festejos argentinos por el Centenario de la Independencia. El jurista brindó una serie de conferencias que tuvieron un gran impacto social y periodístico, tanto en medios nacionales como internacionales. Barbosa fue la visita internacional más importante en la celebración argentina, a tal punto que su presencia condujo al cenit una política de acercamiento entre los dos países, iniciada por el gobierno de Roque Sáenz Peña en 1910 para superar las graves tensiones producidas durante el gobierno de Figueroa Alcorta (19061910). En este sentido, las páginas que siguen examinan los modos en que el célebre jurista embajador logró coronar esta política de aproximación entre los dos países, en un contexto de preocupación mundial por la guerra europea, al tiempo que continuaba en América Latina el clima de los festejos de los Centenarios patrios.

Para ello, en primer lugar, se demostrará la creciente profusión de "embajadas" formales e informales que visitaron uno y otro país en contraste con la década anterior, signada por la desconfianza. Caracterizaremos, 
en segundo lugar, el perfil del jurista embajador, las circunstancias de su aceptación a realizar el viaje y sus consecuencias en el plano nacional, bilateral y mundial. Junto con ello, analizaremos en detalle la performance diplomática, la ritualidad pública y las diversas recepciones de sus discursos durante su estancia en Buenos Aires, así como los ecos posteriores en la prensa y en la diplomacia formal (en este último aspecto destaca particularmente su relación con el jurista, político y periodista argentino Estanislao Zeballos). Por último, nos detendremos en el examen de numerosas cartas que recibió este mediador sociocultural de miembros de los estratos sociales más diversos, incluidos inmigrantes brasileros de la más variada suerte, con el fin de evaluar el impacto social que produjo su embajada.

El trabajo se apoya en diversas fuentes conocidas e inéditas, desde distintos órganos de prensa argentinos y brasileros; artículos de políticos e intelectuales publicados en revistas especializadas en derecho internacional durante la época y documentos inéditos obtenidos en los archivos de las cancillerías de Argentina, Brasil y Chile, hasta la correspondencia personal consultada en el Arquivo Rui Barbosa de la Fundação Casa de Rui Barbosa en Río de Janeiro.

\section{DE LA HIPÓTESIS DE CONFLICTO A LA HIPÓTESIS DE PAZ: AUGE DE LAS NUEVAS “EMBAJADAS”}

Las relaciones diplomáticas entre Argentina y Brasil en el siglo Xx se han caracterizado, como se sabe, por su oscilación entre el polo de la confianza y el de la desconfianza, este último alimentado por una rivalidad que en algunos momentos vislumbró de cerca la posibilidad de una guerra. Uno de estos momentos transcurrió durante el gobierno argentino de José Figueroa Alcorta (1906-1910), especialmente durante la tercera gestión de Estanislao Zeballos como ministro de relaciones exteriores (1906-1908), pero también durante los dos años siguientes, en la medida en que el jurista y periodista argentino continuaba ejerciendo gran influencia en el elenco gobernante, sin dejar de intervenir en la opinión con artículos en la sección internacionales del periódico La Prensa, desde la cátedra universitaria, con su Revista de Derecho, Historia y Letras, y desde su silla de diputado nacional (por tercera vez entre 1912-1916). ${ }^{2}$ La rivalidad personal nacida a partir de la negociación por los territorios de las misiones (1895) con su homólogo, el Barón de Río Branco, repercutió negativamente en las relaciones entre las dos naciones. De

2 Sobre la trayectoria de Estanislao Zeballos puede consultarse, entre otros, Martín O. Castro, “Estanislao Zeballos: sensibilidad diletante, nacionalismo y estado, 1906-1912”, Anuario del Centro de Estudios Históricos 'Profesor Carlos S.A. Segreti', 2015; y Sandra R. Fernández y Fernando Rubén Navarro (eds.), Scribere est agere. Estanislao Zeballos en la vorágine de la modernidad argentina, Rosario, Quinta Pata y Camino Ed., 2011. 
hecho, Zeballos debió abandonar el cargo de ministro a raíz de un telegrama del ministro brasilero que el ministerio había interceptado y hecho público en forma falsificada. La resonante disputa personal se inscribía, sin embargo, en un creciente clima mundial de nacionalismos beligerantes caracterizado por el despegue de carreras armamentistas concentradas en la compra de modernos buques de guerra. ${ }^{3}$ Por entonces, el prestigio de una nación se medía no sólo por el grado de civilización alcanzado y el volumen de su comercio, sino también por el tamaño de su armada.

Desde 1902, los Pactos de Mayo habían desactivado la posibilidad de una guerra entre Argentina y Chile, y fijado entre ambos países una limitación en la compra de armamentos navales. En otro trabajo ${ }^{4}$ hemos demostrado cómo los festejos de los Centenarios de ambos países en 1910 fueron el escenario de la apoteosis de una política de acercamiento político y social. En contraste, la tirantez del gobierno "alcorta-zeballista", tal la expresión de los ministros brasileros en Buenos Aires, con la gestión de Río Branco desembocó en la negativa de enviar embajadas especiales y buques de guerra por parte del Brasil a los fastos argentinos. Más aún, estallaron manifestaciones populares que resultaron en la destrucción de banderas y escudos consulares del país vecino en ciudades argentinas del litoral y también en pueblos del Brasil. Muchos, enardecidos, ofrecían alistarse para una guerra. Una manifestación se dirigió a las puertas del Palacio de Catete para exigirle al presidente Nilo Peçanha la derogación del decreto que establecía el 25 de mayo de 1910 como día feriado en Brasil, una deferencia habitual entre países vecinos. ${ }^{5}$ En la ciclópea Historia de las Relaciones internacionales, sus autores Escudé y Cisneros definen las relaciones entre ambos países en el período que va de 1908 a 1914 como "diplomacia de los acorazados". ${ }^{6}$ No obstante, al aproximar la mirada

3 Algunos trabajos recientes, Cristián Garay, "Las carreras armamentistas navales entre Argentina, Chile y Brasil (1891-1923), Historia Crítica, núm. 48, Bogotá, septiembrediciembre, 2012, pp. 39-57; y Ludolf Waldmann Júnior, “As negociações para limitação de armamentos navais sul-americanos: o caso dos encouraçados no período entre as guerras mundiais", Interfaces da Ciência Política. I Semana de Pós-graduação em Ciência Política, Universidade Federal de São Carlos, s/f.

4 Pablo Ortemberg, "Los centenarios patrios en la construcción de alianzas y rivalidades internacionales: los festejos trasandinos de 1910, la estatua de O’Higgins y los bemoles peruanos", Jahrbuch für Geschichte Lateinamerikas/ Anuario de Historia de América Latina (JbLA), 51, Viena, Colonia, Weimar, 2014, pp. 329-350.

$5 \quad$ Sobre las relaciones entre Argentina, Brasil y Chile durante los fastos de 1910 remitimos a Pablo Ortemberg, "Los centenarios patrios en la construcción de alianzas y rivalidades internacionales: los festejos trasandinos de 1910, la estatua de O'Higgins y los bemoles peruanos", Jahrbuch für Geschichte Lateinamerikas/ Anuario de Historia de América Latina (JbLA), 51, Viena, Colonia, Weimar, 2014, pp. 329-350.

6 Andrés Cisneros y Carlos Escudé (eds.), "La diplomacia de los acorazados (1908-1914)", en ib. Historia General de las Relaciones Exteriores de la República Argentina. Ministerio de Relaciones Exteriores, tomo VII, cap. 37, <http://www.argentina-rree.com/7/7-053.htm>, consultado el 18 de noviembre de 2017. 
a las fuentes diplomáticas y la prensa de la época, nos encontramos con experiencias de acercamiento entre los dos países no del todo condicionadas por la competencia armamentista.

Este movimiento de agudización de la desconfianza en las esferas gubernamentales, con su importante resonancia social, convivió, sin embargo, con crecientes contactos sobre todo intelectuales y periodísticos entre ambos países. Estas visitas - en el caso argentino, con frecuencia como escala portuaria hacia Europa - fomentaban el acercamiento cultural y las impresiones generadas eran difundidas en sus respectivos países a través de los medios de prensa, tal como demuestra recientemente el trabajo de Coelho de Souza Rodrigues centrado en las relaciones entre periodismo y diplomacia. ${ }^{7}$ Este autor percibe en la esfera intelectual un constante estrechamiento de los contactos por las mutuas visitas de periodistas e intelectuales, especialmente desde 1890, con el advenimiento de la república. Estos viajes de periodistas contaron en ocasiones con la aquiescencia gubernamental, constituyendo verdaderas misiones que podrían llamarse de "diplomacia informal" o "embajadas culturales" y que anticipaban lo que luego se denominaría "cooperación cultural". ${ }^{8}$ En ocasiones, la relación entre periodismo, visita cultural y movimientos de la alta política internacional se desarrollaba en un mismo contexto. Por ejemplo, la publicación de Martín García Mérou de $E l$ Brasil intelectual, se dio en el marco de los viajes presidenciales de Julio A. Roca al Brasil en 1899 y de Manuel Ferraz de Campos Salles a Argentina en 1900. ${ }^{9}$ Este caso muestra claramente la doble vocación de escritor y diplomático de García Mérou, cualidades presentes en muchos ministros durante el período. El carácter polifacético de muchos de estos mediadores culturales (diplomáticos, escritores, periodistas, juristas y hombres de ciencia) complica diferenciar taxativamente una visita cultural de una visita oficial. Además, el carácter "oficial" que puede atribuirse a una visita, o la distinción

7 Joao Coelho de Souza Rodrigues, "Embaixadas originais: diplomacia, jornalismo e as relações Argentina-Brasil (1888-1935)”, Topoi (Río de J.). Río de Janeiro, vol. 18, no. 36, set-dic, 2017, pp. 537-562. También remitimos a la tesis de maestría de Lyanna Carvalho, "A cultura nas representações argentinas sobre o Brasil”, Programa do pós-graduação em Letras e Linguística, Faculdade de Letras, Universidade Federal de Goiás, Goiânia, 2014, 193 pp.; Diego A. Molina, "Argentina y Brasil en tres acercamientos”, Abehache, año 4, no. 7, 2o sem., 2014, pp. 10-32; y Ori Preuss, Transnational South America: experiences, ideas, anda identities, 1860s-1900s, Londres-New York, Routledge, 2016.

$8 \quad$ Joao Coelho de Souza Rodrigues, op. cit., p. 545.

9 La ritualización e innovación en los recorridos de las visitas culturales en Paula Bruno (coord.), Visitas culturales en la Argentina (1898-1936), Buenos Aires, Biblos, 2014. Sobre la actuación diplomática de García Mérou, Paula Bruno, "Martín García Mérou entre Brasil, Argentina y Estados Unidos. Observaciones para pensar el fin-de-siglo americano", en AA.VV, Gregorio Weinberg: escritos en su honor. Premio Gregorio Weinberg a la Investigación en Historia de la Educación, la Ciencia y la Cultura Latinoamericanas, Buenos Aires, Clacso, 2017, pp. 25-53. 
entre su cariz "formal" o "informal", debe problematizarse. Reduccionismos tales nos impiden dar cuenta de la heterogeneidad de actores vinculados entre sí que participaban en estas experiencias. Personas o grupos muy distintos en su perfil y objetivos viajaban al encuentro de sus homólogos: por ejemplo, comisiones de policías, grupos de periodistas en representación de tal o cual órgano de prensa, comisiones parlamentarias, delegaciones de médicos, académicos en representación de su alma mater o de diferentes institutos de los que formaban parte, etcétera. Los viajes más frecuentes eran motivados por la realización de un congreso internacional, los cuales, a su vez solían formar parte del programa de una conmemoración nacional, tal como ocurrió durante los festejos de los centenarios patrios. Casi todos estos mediadores culturales, al llegar, participaban de eventos sociales (banquetes, conferencias, visitas a museos, tés sociales, paseos establecidos en la ciudad y sus alrededores) y también gubernamentales, en la medida en que eran recibidos por funcionarios locales y por lo general eran auspiciados también por su propio gobierno en contacto con el personal de la legación en el extranjero. La multiplicación de congresos y viajes de "embajadas" o delegaciones especializados acompañó la diferenciación y profesionalización de los campos periodístico, literario, educativo, jurídico y científico. ${ }^{10}$

Lo anterior nos obliga a considerar, por lo tanto, varias dimensiones y actores que intervienen al mismo tiempo por diferentes vías en la construcción de las relaciones políticas y culturales entre los Estados. Por lo menos, debemos tener en cuenta la relación entre tres grandes vectores: el gubernamental desde las carteras ministeriales, el del mundo intelectual anclado en instituciones académicas y en órganos de prensa, y las corrientes de simpatías populares. El alcance de estas últimas puede rastrearse en las notas de los ministros de las legaciones, en la prensa local (notas que a la vez estimulan y registran estas simpatías) y, cuando las fuentes lo posibilitan, en las cartas y solicitudes populares conservadas en archivos personales o de las cancillerías. En lo que sigue indagaremos en algunas experiencias que consideramos significativas en la deriva de las relaciones entre los dos países donde intervinieron "embajadas" que involucraron estos tres niveles, aunque nos detendremos especialmente en las que preponderó el vector gubernamental. Esto permitirá comprender el contexto en el que se inscribe la embajada a la vez "oficial" y académica de Ruy Barbosa en 1916.

Inmediatamente después de los festejos de los Centenarios argentino y chileno de 1910, varios factores posibilitaron un importante cambio en las

10 En la deriva de las relaciones internacionales no carece de importancia la profusión de "embajadas" de deportistas. Por ejemplo, contribuyó al conocimiento mutuo la celebración de la Copa Roca disputada por las dos selecciones desde el año 1914; o el encuentro en Buenos Aires de la primera copa sudamericana jugada en el marco del Centenario de 1916 entre los países del ABC junto con Uruguay. 
relaciones entre Argentina y Brasil. En agosto de ese mismo año, Roque Sáenz Peña, como presidente electo, aceptó la invitación del gobierno brasilero para ser huésped de honor en Itamaraty antes de arribar a Buenos Aires en su viaje de regreso de Europa. El acontecimiento fue considerado como "un triunfo" por el Barón de Rio Branco. El ministro chileno en Río de Janeiro enviaba una nota a su Cancillería donde apuntaba:

muéstrase el Canciller brasilero muy complacido con la visita que hará a Río de Janeiro el señor Sáenz Peña. Lo mira algo así como un triunfo, por lo mismo que sus relaciones con el actual gobierno son tan frías. Entretanto, el señor Sáenz Peña le ofreció a su paso para Europa, detenerse aquí cuatro días al regreso, y según noticia recibidas por el Barón cumplirá su promesa. Le espera el día 18 de agosto. Se le alojará en el Palacio Isabel, que había sido restaurado y preparado para recibir al Rey don Carlos de Portugal, el mismo en que pensó hospedar a nuestro Presidente cuando se habló de su posibilidad de su venida al Brasil. ${ }^{11}$

El gobierno brasilero envió luego una embajada extraordinaria y varios navíos a la ceremonia de asunción de Roque Sáenz Peña el 12 de octubre (según Estanislao Zeballos, chilenos y uruguayos se sintieron en obligación de imitar). La misión estaba presidida por Alberto Fialho quien había tejido amistad con el nuevo presidente años antes cuando coincidieron en Roma, y también había sido ministro de la legación en Buenos Aires. Fialho regresó a su país con las mejores impresiones de la sociedad porteña, pese a los comentarios hostiles que todavía destilaba La Prensa bajo el influjo de Zeballos. En esta ocasión, el periódico impugnaba la actuación del gobierno brasilero mediante la institución "embajatoria" (una polémica que iba más allá de las relaciones entre Argentina y Brasil) y lamentaba que las cortesías del gobierno brasilero no hubieran estado presentes oportunamente durante los festejos de Mayo. ${ }^{12}$

Por su lado, en retribución, el gobierno argentino envió para la asunción presidencial del Mariscal Hermes da Fonseca a mediados de noviembre una embajada extraordinaria en los cruceros "Buenos Aires" y "Patria". Compuesta por numerosos militares y marinos, iba presidida por el diputado doctor Manuel

11 Archivo Histórico de la Cancillería de la República de Chile, Fondo Argentina, V. 214 (1910), oficio confidencial del ministro chileno en Río de Janeiro transmitido por el ministro de relaciones exteriores Luis Izquierdo al ministro Miguel Cruchaga en Buenos Aires, Santiago, 18 de agosto, 1910. Roque Sáenz Peña ahora se distanciaba claramente de Zeballos y de otros políticos favorables a la doctrina del destino manifiesto con quienes había coincidido en su momento, véase: Martín O. Castro, op. cit. Como veremos a continuación, Roque Sáenz Peña no es el único que se redime de ese agresivo pasado armamentista, también lo harán, entre otros, Manuel A. Montes de Oca y Victorino de la Plaza.

12 Arquivo Histórico del Itamaraty, Río de Janeiro (en adelante ACB), Oficio, 1910 (juliodiciembre), 206-2-08, nota del ministro Domicio Da Gama al ministro de relaciones exteriores, Baron de Rio Branco, 21 de octubre de 1910. "La recepción del Embajador del Brasil", La Nación, 15 de octubre, 1910; "Actualidad. Las embajadas extraordinarias", La Prensa, 11 de octubre de 1910. 
Augusto Montes de Oca como embajador extraordinario y plenipotenciario, y acompañado por el doctor Matías Sánchez Sorondo como secretario de la embajada. Aunque algunos periódicos argentinos pusieron en cuestión la elección de quien había fomentado la campaña armamentista, años antes, cuando era ministro de relaciones exteriores de Figueroa Alcorta — meses antes de dejarle el lugar a Zeballos-, nada de esto trascendió en la opinión brasilera y la misión de confraternidad resultó un éxito. ${ }^{13}$ La víspera de la ceremonia de asunción destacaban en la bahía los dos buques argentinos, junto con uno francés y otro uruguayo (este también en misión especial de confraternidad, presidida por José Espalter). Más tarde arribó el navío "Adamastor" en representación de Portugal. ${ }^{14}$

A su regreso, los testimonios de los embajadores argentinos ante la prensa local expusieron una plétora de halagos al gobierno y pueblo brasileños por el trato brindado durante la breve estadía. Simbólicamente, podría decirse que se dramatizó una mutua reparación al agravio de banderas acontecido meses antes en los candentes días de mayo: el día del traspaso de mando, en diversas ciudades del Brasil, "manifestaciones populares saludaron con vítores y aplausos a la bandera argentina, izada en los respectivos consulados". ${ }^{15} \mathrm{El}$ vicecónsul de Uruguayana, por ejemplo, envió un telegrama para comunicar que "autoridades civiles y militares y el pueblo reuniéndose frente [a] este viceconsulado hicieron espontánea y entusiasta demostración de aprecio a la Nación Argentina, reponiendo en ese acto el escudo y pabellón argentinos que habían sido retirados violentamente por un grupo de populares en el mes de Mayo". ${ }^{16}$ Por su parte, dos días después, la marinería argentina desfiló por las calles de Río para honrar el día de renovación republicana del juramento al pabellón brasileño y se prestó a tocar el himno del anfitrión con su propia banda de música, un gesto que no estaba previsto en el programa de actividades.

13 Sobre estas reservas, "Cortesías internacionales. Los embajadores", El Día (Buenos Aires), 25 de octubre de 1910.

14 "Representações estrangeiras", Jornal do Brasil, 14 de noviembre de 1910; "As embaixadas", O Paiz, Río de Janeiro, 17 de noviembre de 1910. Al finalizar la misión, según carta confidencial de Julio Fernández ministro argentino en Río de Janeiro al ministro de relaciones exteriores señor Ernesto Bosch, la embajada uruguaya, presidida por el doctor José Espalter, fue menos lucida que la argentina, aunque, a su juicio, esa apariencia no se condecía con la deferencia que Río Branco había observado con ella en privado. Archivo del Ministerio de Relaciones Exteriores y Culto de la República Argentina (en adelante ACA), Caja AH/0062, 1910, Misiones al exterior, Montes de Oca, Brasil. Confidencial, ministro Julio Fernández, Río de Janeiro, 2 de diciembre de 1910.

15 La Nación, Buenos Aires, 28 de noviembre de 1910.

16 ACA, Caja AH/0062, 1910, Misiones al exterior, Montes de Oca, Brasil. Telegrama del vicecónsul de Uruguayana al Ministro de Relaciones Exteriores, Ernesto Bosch, 17 de noviembre de 1910 . 
La población fluminense ovacionó entonces a Montes de Oca y a los marinos por distintas calles y plazas. ${ }^{17}$

Pese al creciente clima de cordialidad, circularon rumores en la prensa argentina con respecto al objetivo de la misión de Montes de Oca, asegurando que pretendía conseguir acuerdos sobre equivalencia naval con Brasil. El diputado tuvo que desmentirlo en más de una entrevista. Lo cierto es que este tema no dejaba de estar presente en la agenda de los países y repercutía constantemente en la opinión. Fueron las gestiones simultáneas de Ramón J. Cárcano las que lograron un acuerdo para evitar que ambos gobiernos adquirieran un tercer acorazado. ${ }^{18}$

En cierta medida, la muerte del Barón de Río Branco en 1912 trajo aires de mejoría para las relaciones entre los dos países bajo las gestiones de Lauro Müller y luego Félix Pacheco en el Ministerio de Relaciones Exteriores. Contribuyó a este cambio la acertada denominación de Campos Salles, ese mismo año, como embajador extraordinario en Buenos Aires y, en correspondencia, la designación del ex presidente Roca como ministro en Río de Janeiro. El alto rango de las personalidades elegidas llegó a inquietar ligeramente al gobierno chileno. En efecto, la recepción de Campos Salles en la capital argentina tuvo grandes expansiones en la opinión y hasta fue comentada en la prensa de países distantes. Por ejemplo, un diario de Quito reproducía el siguiente telegrama:

Grandiosa recepción (...) pone de manifiesto la buena cordialidad entre los dos pueblos. Al muelle fue a esperarlo el general Roca. Al encontrarse los dos antiguos ex presidentes se dieron un afectuoso abrazo, abrazo que la concurrencia aplaudió con entusiasmo inmenso (...) se hacen comentarios sobre (...) la primera vez que se abrazaron... y (...) que los dos pueblos marcharán unidos en el futuro. ${ }^{19}$

17 ACA, Caja AH/0062, 1910, Misiones al exterior, Montes de Oca, Brasil. Nota de Montes de Oca al Ministro de Relaciones Exteriores, Ernesto Bosch. Buenos Aires, 5 de diciembre de 1910; ACA, Caja AH/0062, 1910, Misiones al exterior, Montes de Oca, Brasil. Nota del cónsul Carlos Lux Klett al Ministro de Relaciones Exteriores. Río de Janeiro, 21 de noviembre de 1910. También son comentados la ejecución de himnos, los homenajes a las banderas y el entusiasmo popular en "A Marinha Argentina", O Paiz, Río de Janeiro, 19 de noviembre de 1910.

18 Véaser Rosendo Fraga, Ramón J. Cárcano diplomático. La historia como instrumento de la diplomacia. Buenos Aires, CARI (Consejo Argentino para las Relaciones Internacionales), Serie Los Diplomáticos, núm. 18, 1999, p. 14.

19 ACB, Misiones diplomáticas brasileras, Quito, 1910-1912, 228-1-20, recorte de periódico de Quito, s/r, enviado por ministro brasilero Jarbas Loreti al Ministro de Relaciones Exteriores Lauro Müller, Quito, 23 de abril de 1912. Lauro Müller anhelaba por medio de esta designación un "estreitamento cada vez maior dos laços de boa amizade que felizmente nos unem”, ACB, Telegramas, 208-2-12, telegrama de Lauro Müller a Legación en Buenos Aires. Río de Janeiro, 21 de marzo de 1912. En otro telegrama, agradece a Campos Salles su colaboración para una política que "nos deverá irmanar para sempre" con el pueblo argentino. ACB, Telegramas, 208-2-12, telegrama de Lauro Müller a Campos Salles, Río de Janeiro, 17 de abril de 1912. 
En ocasión de celebrarse el cuarto de siglo de la república brasilera y la asunción presidencial de Venceslau Brás, el 15 de noviembre de 1914, el gobierno argentino envió una embajada extraordinaria. La corveta La Argentina fue la primera en saludar con sus cañones a la bandera de la república hermana.

Este clima de crecientes acercamientos diplomáticos puestos en escena mediante el envío de embajadas oficiales y buques de guerra, con amplia resonancia popular gracias a los órganos de prensa, posibilitó, el 25 de mayo de 1915, la concreción del añorado Pacto ABC, cuyo antecedente inmediato, como habitualmente se anota, fue la participación conjunta de Argentina, Brasil y Chile en las conferencias de Niagara Falls en 1914, en un intento de mediación en el conflicto entre Estados Unidos y México. El Pacto de No Agresión, Consulta y Arbitraje no fue ratificado por Argentina, aunque siguió gravitando en las iniciativas de acercamientos entre los tres países durante los años sucesivos.

La novedosa confraternidad política y social alcanzada entre Brasil y Argentina quedará comprobada a lo largo de 1915 no sólo con la firma del Pacto $\mathrm{ABC}$, sino también económicamente por la instalación de la Cámara de Comercio argentino-brasileña y, simbólicamente, por el modo exultante en que se celebró en Buenos Aires el aniversario de la Independencia brasilera. ${ }^{20}$ En el marco de la conmemoración del "Grito de Ipiranga", el diario $\mathrm{La}$ Nación apuntaba al final de su nota: "los vínculos de fraternidad que a ella [la "nación amiga"] nos unen son cada vez más estrechos que nunca". ${ }^{21}$ Este triple movimiento de acercamiento político, económico y cultural entre Argentina y Brasil alcanzará su apoteosis durante los festejos por el Centenario de la Independencia.

Simultáneamente, el estallido de la Gran Guerra europea no hizo sino contribuir al estrechamiento de lazos entre los países de la región y, como han analizado varios autores, aceleró la consolidación de la idea de América como un continente de paz en contraste con la barbarie que se extendía en el Viejo Continente, modelo civilizatorio puesto ahora en cuestión. ${ }^{22}$ De hecho, la convicción, tal como examina en su obra Olivier Compagnon, de 1915; "Cámara de Comercio argentino-brasileña. La reunión de anoche”, La Nación, 28 de agosto de 1915.

21 "El Grito de Ipiranga", La Nación, 7 de septiembre de 1915.

22 Puede consultarse, entre otros, Olivier Compagnon, América Latina y la Gran Guerra. El adiós a Europa (Argentina y Brasil, 1914-1939), Buenos Aires, Crítica, 2014; trabajos de María Inés Tato, como, por ejemplo, el dossier que coordinó recientemente: María Inés Tato, "A cien años de la Primera Guerra Mundial: una aproximación a su impacto en la Argentina", PolHis. Revista Bibliográfica del Programa Interuniversitario de Historia Política, Mar del Plata, 2015. Sobre el impacto de la guerra europea en el mundo del Derecho Internacional en Sudamérica, Juan Pablo Scarfi, The Hidden History of International Law in the Americas: Empire and Legal Networks. New York, Oxford University Press, 2017 (cap. 4, pp. 87-118). 
que Sudamérica encarnaba el paradigma de paz estaba extendida en muchos discursos de las elites brasileras y argentinas. En este sentido, este investigador ofrece una rica historia comparada del involucramiento de las dos naciones en el conflicto mundial, y examina los modos en que cada sociedad repensó su identidad nacional y el destino de América Latina. ${ }^{23}$ Enmarcado en este clima general de ideas, nuestro trabajo se interesa por el acercamiento político entre estos dos países, para dar cuenta de cómo influyó la Gran Guerra en la culminación de un ciclo de estrechamiento de lazos que llegó a su máximo despliegue en la conmemoración de 1916.

\section{La Embajada de RuY Barbosa en las CONMEMORACIONES ARGENTINAS DE 1916}

Si el Centenario de Mayo de 1910 tuvo como invitado de honor al presidente chileno, el Centenario de la Independencia en 1916 dedicó sus más entusiastas agasajos a la visita del embajador brasilero, el insigne internacionalista Ruy Barbosa. En efecto, esta figura fue el invitado de mayor rango en los festejos que tuvieron lugar en Buenos Aires y la que recibiera mayores atenciones, incomparables con las brindadas a los delegados latinoamericanos que participaron en el Congreso de Ciencias Sociales en Tucumán y en el I Congreso Americano del Niño, eventos enmarcados dentro del programa de festejos. La ausencia de visitas oficiales de Europa se debió a la guerra y a la interrupción de las comunicaciones atlánticas de ella derivada, así como también a la imposibilidad de realizar pomposos festejos debido a la crisis económica que atravesaba la Argentina, junto con las expectativas locales puestas en la asunción en octubre del presidente radical Hipólito Yrigoyen, quien había obtenido la victoria electoral en abril de ese año gracias a la Ley Sáenz Peña. ${ }^{24}$

Acorde con el espíritu ABC, el ministro argentino en Río de Janeiro, Lucas Ayarragaray, se ocupó en averiguar si Chile y Estados Unidos enviarían embajadas numerosas al Centenario de Julio, "para regularla de aquí". ${ }^{25}$ Sin embargo, el gobierno brasilero le manifestó que aun cuando ningún país

23 Olivier Compagnon, op. cit. Recomendamos sobre este tema su capítulo 5: "Nocturno europeo", pp. 205-245.

24 Un reciente análisis de estos festejos en Pablo Ortemberg, "El Centenario de la Independencia de 1916: tradiciones patrióticas, prácticas modernas e imágenes de progreso en el espejo de 1910", PolHis. Revista Bibliográfica del Programa Interuniversitario de Historia Política, año 9, núm. 18, julio-diciembre, 2016, pp. 103-143.

25 ACA, Argentina, caja Ceremonial-Varios, 1916, caja 13, Expediente Brasil, telegrama cifrado 428 del ministro en Río de Janeiro, Lucas Ayarragaray, al ministro de relaciones exteriores, José Luis Murature, Río de Janeiro, 24 de mayo de 1916. 
americano enviara embajada, su país tenía resuelto designar una delegación. ${ }^{26}$ El presidente Venceslau Brás y su ministro Lauro Müller consideraron que el ya mundialmente célebre "Águila de La Haya", ${ }^{27}$ el jurista e intelectual de mayor renombre del país, era la personalidad ideal para acudir a los festejos argentinos como Embajador Extraordinario y Plenipotenciario en representación del Brasil. Barbosa tenía por entonces 67 años de edad y su contextura menuda lo hacía parecer aún más frágil de lo que era. Su tendencia a la gripe lo hacía temer por su salud en el invierno de Buenos Aires y este fue el motivo que adujo para intentar desistir ante la insistencia de Lauro Müller. ${ }^{28}$ Finalmente, Ayarragaray recibió a fines de mayo la confirmación personal de su aceptación. ${ }^{29}$ Además de su indiscutido renombre, Barbosa poseía un profundo conocimiento de la historia argentina, había aprendido el español — según él, a partir de sus lecturas-y no dejó de mencionar en sus discursos que había sido recibido con hospitalidad en la capital del Plata durante su exilio en 1893. En este punto de su vida profesional no sorprende la extensa red de amistades políticas e intelectuales. Entre ellas, comentaba en entrevista que había cultivado amistad con los doctores Manuel Quintana (1835-1906) y Luis María Drago (1859-1921). Sin embargo, hasta su viaje de 1916 nunca había visto en persona al ex ministro Zeballos, quien encarnaba como ninguno la figura del "enemigo del Brasil". En 1908, Barbosa había tenido que replicar acusaciones de Zeballos por su actuación en La Haya. ${ }^{30}$

La embajada quedó conformada por Ruy Barbosa a la cabeza como Embajador Extraordinario y Plenipotenciario, acompañado por su señora y dos hijas, el general Feliciano Mendes de Moraes como delegado militar, el contraalmirante Antonio Coutinho Gomes Pereira como delegado naval, Antonio Batista Pereira y Joao Rui Barbosa (el hijo, también junto a su esposa) como secretarios, el teniente Adolfo Acunha Leal como "Ajudante-de-Ordens", el capitán Armando Duval como Agregado Militar, Lourival de Guillobel como secretario de embajada. La nominación fue recibida con entusiasmo por periódicos de ambos países. Escribe para La Nación un cronista desde Río de Janeiro: "Para saludar a la Argentina el Brasil envía, pues, como lo ha escrito

26 Ibid., telegrama 430.

27 En 1907 fue deslumbrante su participación como delegado del Brasil en la II Conferencia de La Haya.

28 Existen dos obras destacables por su minucioso tratamiento del paso de Barbosa por Buenos Aires. Una de ellas es el prefacio escrito en 1978 por Evaristo de Moraes Filho en Ministério de Educação e Cultura, Fundação Casa de Rui Barbosa, Obras completas de Rui Barbosa, vol. 43 (1916), tomo 1, Río de Janeiro, 1981, “A Embaixada a Buenos Aires”, IX-XCII; y otra, Regina Monteiro Real, Rui Barbosa em Buenos Aires. Cinquentenário da Embaixada a Buenos Aires, 1916-1966. Río de Janeiro, Fundação Casa Rui Barbosa, 1969.

29 ACA, Argentina, caja Ceremonial-Varios, 1916, caja 13, Expediente Brasil, telegrama reproducido por el ministerio de relaciones exteriores y comunicado al ministerio del interior, Buenos Aires, 31 de mayo de 1916.

30 Evaristo de Moraes Filho, op. cit., p. XI. 
el Jornal do Commercio, el más alto exponente de nuestra intelectualidad. Como embajador, él sabrá mejor que ninguno de nosotros deciros la honda sinceridad con que nos asociamos a vuestro glorioso centenario". ${ }^{31}$ Antes de la partida, a comienzos de junio, la Academia de la Universidad de Buenos Aires comunicaba al Ministerio de Relaciones Exteriores argentino la decisión "por unanimidad" de nombrar a Barbosa académico honorario. ${ }^{32}$ Esta designación honorífica por parte de la Universidad, por mediación de la Cancillería, manifestaba un homenaje que preparaba el terreno de cordialidad de la visita y generaba de antemano un compromiso de Barbosa con el mundo académico local. Su celebrada estancia se circunscribió a la ciudad de Buenos Aires - con un paseo en la lancha presidencial por El Tigre - y duró exactamente un mes, del 28 de junio al 29 de julio. El momento culminante de su actuación fue la conferencia pronunciada en el aula magna de la Facultad de Derecho de la Universidad de Buenos Aires el 14 de julio cuando recibió el diploma de miembro honorario de esa institución académica por su contribución al mundo del derecho como jurista en la Conferencia de La Haya de 1907 y sus trabajos sobre la legislación civil, según las propias palabras del rector en el instante de la ceremonia. Veremos con más detalle algunos aspectos de esta conferencia para comprender la dinámica de este tipo de diplomacia cultural que conecta una dimensión "oficial" con otra propia de un saber especializado, y ambas con singular repercusión en el sector popular.

El senador viajó en el vapor "Júpiter" con escala en Montevideo. También venía el crucero "Almirante Barroso" para participar en la revista naval del Centenario y en los desfiles militares. La embajada desembarcó en Buenos Aires el 4 de julio. Fue recibido por una gran concurrencia en el puerto, entre ellos, Alberto Santos Dumont, quien se encontraba de paso en Buenos Aires - regresó al Brasil con la comitiva por invitación de Barbosa- y otros miembros de la colonia brasilera. ${ }^{33}$ Fue directamente al Hotel Plaza, donde se alojaría como huésped del gobierno durante toda su estadía y en cuyos salones ofrecería eventualmente tés y banquetes para retribuir algunas de las numerosas invitaciones a las que tendría el honor de asistir. La reciprocidad de agasajos era usual en las esferas de la diplomacia formal, aunque previsiblemente el visitante diplomático nunca alcanzaba a corresponder en número y volumen a las invitaciones que le cursaban personalidades locales, carteras ministeriales,

31 "Del Brasil, Ruy Barbosa, para La Nación, Río de Janeiro, junio de 1916", firmado por Jacques Petiot, La Nación, 2 de julio de 1916.

32 ACA, Argentina, caja Ceremonial-Varios, 1916, caja 13, Expediente Brasil, telegrama del ministro José Luis Murature al Encargado de negocios en Río de Janeiro, 19 de junio de 1916.

33 Fue recibido con gran presencia de ministros y secretarios, pero también por amplios sectores populares. A Rua. Semanario Ilustrado. Río de Janeiro, 4 de julio de 1916, p. 1. Es importante señalar que la colonia de brasileros en Buenos Aires no representaba un número significativo en comparación con otras nacionalidades. Careta, Río de Janeiro, 12 de agosto de 1916, p. 5. 
clubes, instituciones y asociaciones. Por la tarde compareció ante el ministro de relaciones exteriores, José Luis Murature. Por esas curiosas ironías de las efemérides, como el 4 era la fecha de la independencia norteamericana saludó con su comitiva al embajador norteamericano Frederic Stimson antes de presentar las credenciales de embajador, al día siguiente, ante el presidente Victorino de la Plaza. Al final de la jornada concedió una entrevista a La Nación en la que deseó que ese periódico fuera el portavoz de su afecto ante el pueblo argentino. ${ }^{34}$ El primer día también recibió en el Hotel Plaza la espontánea visita de Estanislao Zeballos.

En su discurso de presentación de credenciales quedó cifrado el sentido que daba a su misión y los tópicos que ocuparían en sus conferencias sucesivas. En primer lugar, una lectura teleológica sobre la madurez republicana y democrática de Argentina, en la que no escatimará elogios a la ley Sáenz Peña. Dijo, "...meu Governo, investindo-me na distinção de representar a Nação brasileira nas solenidades comemorativas desse acontecimento [la Declaración de la Independencia] capital na história da liberdade y da democracia". ${ }^{35}$ Em segundo término, aparece el motivo principal de la misión en esa clave:

vir ao encontro do coração argentino com o coração brasileiro, e consagrar debaixo dos auspícios do mais augusto dos vossos fastos nacionais a emoção da verdadeira fraternidade, com que minha Pátria abraça a sua gloriosa irmã, a quem o adiantamento na cultura das instituições liberais e a magnificência da sua civilização asseguram um dos primeiros lugares na família dos Estados republicanos. ${ }^{36}$

Barbosa evoca a su vez como antecedente inmediato de su embajada a aquella enviada por el gobierno argentino en noviembre de 1914 para homenajear el cuarto de siglo de la república en Brasil junto con la asunción del actual presidente Brás. Recuerda luego su antiguo afecto con la Argentina y enfatiza la necesidad de construir lazos de sincera amistad y real confianza entre los dos países. Posteriormente, algunos comentaristas valorarán el hecho de que el responsable de esta misión no fuese un diplomático de carrera o un ministro de turno pues encontraban que en la voz de Barbosa las palabras de confraternidad brotaban de una emoción sincera.

Por último, Barbosa alude a su preocupación personal y a la conmoción mundial vivida en aquellas horas frente a guerra que se libraba en Europa. En particular, lo desanimaba profundamente el quebrantamiento del derecho y de las convenciones logradas en La Haya: "No meio das calamidades espantosas,

34 Expresa en la entrevista: "deseo sinceramente, muy sinceramente que La Nación sea el honroso portavoz de mis palabras de afecto a este gran país sudamericano", Obras completas cit., "Entrevista de La Nación", p. 7-9.

35 "Apresentação de credenciais", Obras completas ... cit., p. 3-6.

36 Ibíd., p. 4. 
que neste momento arruínam uma das metades do mundo civilizado, e repercutem dolorosamente na outra, as regiões que tem escapado a zona imensa do turbilhão servem de refugio aos elementos de paz, trabalho e justiça". ${ }^{37}$ Estas circunstancias obligaban, según él, a la Argentina y al Brasil a fortalecer la cooperación y consolidar por vías del derecho la resolución pacífica de conflictos. Así alcanzaba su apogeo el ciclo de misiones de aproximación entre Brasil y Argentina del período iniciado 1910: con discursos de confraternidad de un jurista embajador propiciados por el paisaje de horror que ofrecía la Gran Guerra.

Un volumen de las obras completas de Barbosa reproduce las conferencias y discursos más importantes que brindó durante el mes que permaneció en Buenos Aires. ${ }^{38}$ Además del discurso de presentación de credenciales, el día de su arribo ofreció la citada entrevista a La Nación, impartió luego la famosa conferencia en la Facultad de Derecho de la Universidad de Buenos Aires, además de discursos en el Senado (mencionó profusamente El Brasil intelectual de García Mérou), en el Círculo Militar (en homenaje de los veteranos de la Guerra del Paraguay expresó su oposición al militarismo, pero su apoyo a un ejército respetuoso de la democracia) y en el Jockey Club (ante el presidente argentino); fue asimismo relevante la conferencia que pronunció en el Instituto Popular de Conferencias del periódico La Prensa (invitado por Estanislao Zeballos). El volumen también reproduce varios discursos que ofreció a su regreso en Brasil, cuando recibió saludos de diversas autoridades, instituciones y medios de prensa. Nos interesa aquí detenernos en algunos aspectos referidos a sus dos conferencias más importantes, tanto por la relevancia que adquirieron (en el caso particular de la pronunciada el 14 de julio), como por su trascendencia en la construcción de las relaciones de confraternidad, por mediación del jurista internacionalista, entre los dos países.

La conferencia del 14 de julio en el aula magna de la Facultad de Derecho y Ciencias Sociales fue pronunciada en un exquisito español ${ }^{39}$ durante tres horas y media, dejó impresionado al auditorio y tuvo inmediata repercusión en la prensa argentina, brasilera y mundial. Además de ser reproducida en la prensa, fue incorporada por entusiasta moción en los anales del Senado Federal y de la Cámara de Diputados del Brasil. Intitulada "Conceptos modernos del derecho internacional" y publicada luego como "El deber de los neutrales", su núcleo argumentativo exhortaba al compromiso activo de los países no beligerantes con las convenciones del Derecho Internacional. Ningún gobierno neutral podía mantenerse pasivo ante la invasión de Bélgica ni de cualquier otro país declarado neutral.

Ibid., pp. 4-5.

Obras Completas...op. cit., pp. 3-229, más apéndices, pp. 230-288.

La había escrito en portugués y se la tradujo en Río su amigo Manuel Bernárdez, ministro de Uruguay. 
Por supuesto, la resonancia internacional que tuvo su conferencia de la Facultad de Derecho fue posible gracias al capital simbólico internacional que ya había acumulado el jurista a lo largo de su vida. Desde sus jóvenes alegatos como abolicionista y luego por el nombramiento como Conselheiro del emperador, codificador de la constitución republicana, posteriormente, por su carrera política (aunque derrotado en elecciones presidenciales) y en particular, por su exitoso desempeño como delegado en La Haya ya era una luminaria de fama mundial. La conmemoración de la Independencia argentina fue la caja de resonancia o el canal que el destino puso a su disposición para expandir su exhorto de jurista internacionalista frente a la contienda europea que por entonces dividía al mundo entre aliadófilos y germanófilos, alteraba el curso del comercio internacional y repercutía en la fe en el mundo civilizado y el orden liberal. La conferencia se tradujo a numerosos idiomas, recibió cartas de felicitaciones de personas, instituciones y asociaciones de todas partes del mundo, el gobierno francés lo invitó a París — nunca regresó a Europa- - en el plano local sus colegas, con un redimido Estanislao Zeballos a la cabeza, lo colmaron de elogios. Con todo, sus enemigos internos no dejaron de impugnar varios aspectos de su misión, concentrados en las dos conferencias más importantes. Vale la pena detenernos por ello en la segunda en importancia.

Días después de su lucimiento en la Facultad de Derecho, fue presentado por Zeballos en el Instituto Popular de Conferencias del periódico La Prensa donde dio otra extensa conferencia en la que destacó las virtudes de su anfitrión, aseguró que toda nube de conflictos con el ex ministro argentino había quedado en el pasado; acorde con el espacio donde se hallaba resaltó su primigenio papel como periodista, su amada vocación, y desde ese lugar identitario confraternizó con los colegas argentinos en un pasaje en que no ahorró elogios a La Prensa y a La Nación, los dos "colossos" del periodismo sudamericano. ${ }^{40}$ Es interesante advertir que en sus posteriores apologías Barbosa arguyó que en la primera conferencia había hablado como jurista y miembro permanente del Tribunal de La Haya y no como diplomático representante de la política exterior del Brasil. ${ }^{41}$ En el mismo texto de la segunda conferencia destacaba su experiencia como periodista para confraternizar por sobre la identidad nacional: "se não somos da mesma nacionalidade, somos do mesmo oficio". ${ }^{42}$ Esto demuestra la versatilidad del lugar de enunciación de los embajadores

40 Un desarrollo sobre la importancia de los viajes de los periodistas en la construcción de la confraternidad entre Argentina y Brasil en Joao Coelho de Souza Rodrigues, op. cit. Más aún, las visitas importantes que llegaban a Buenos Aires eran invitadas a conocer las redacciones de estos diarios, una parada casi obligada. Sobre los circuitos de paseos de visitantes ilustres, véase: Paula Bruno (coord.), op. cit., 2014.

$41 \quad$ Así lo enfatizaba convenientemente el neutralista Manuel Oliveira, "La neutralidad del Brasil", Revista de Derecho, Historia y Letras. Buenos Aires, Peuser, tomo LV, 1916 , pp. 207-210.

$42 \quad$ Obras completas..op. cit., p. 124. 
culturales en misión oficial y las estrategias retóricas a las que podían acudir para despertar empatía en beneficio de la misión de acercamiento. En algunas notas periodísticas se destacaba la eficacia de las embajadas presididas por altas personalidades de la cultura antes que por comunes ministros de legación en su cometido de estrechar lazos genuinos. Sin ir más lejos, días antes de pronunciar sus conferencias, Zeballos le escribió a Barbosa una carta que firmó como "amigo y viejo admirador", donde le aseguraba que "nadie fue recibido aquí como V. E. Para otros brasileños eminentes, sin excluir a Campos Salles, hubo reservas. Ellos tuvieron acogida oficial, V. E. la tuvo nacional, pero el alto carácter de V. E. nos inspira confianza a todos. Por eso también V. E. puede hacer lo que otros no hicieron". ${ }^{43}$

Lo cierto es que hasta el periódico anarquista La Protesta, que no adhería al festejo nacional y rechazaba con virulencia las celebraciones patrióticas, fue seducido por la conferencia de Barbosa en la Facultad de Derecho a la que calificó de "brillante" y, dice la nota de este periódico, "sobre la que a fuer de sinceros, nos hemos pronunciado favorablemente, si bien, lo que es lógico, asombrándonos al mismo tiempo de que el viejo político 'brasileiro' fuese un fenómeno de excepción en los accidentados anales de la diplomacia proxenetill" ${ }^{44}$ Aunque en el párrafo seguido el autor de la nota lamentaba que sus conceptos internacionalistas los hubiera desmentido en la siguiente conferencia que brindó en el Instituto Popular de Conferencias, en la que “alabó, en efecto, a los 'colosos' del diarismo criollo, a 'nuestro' ejército, a 'nuestra' ciudad, y a otra gran porción de cosas 'nuestras". ${ }^{45}$

En efecto, no todo fueron rosas para la misión del afamado jurista. El subsecretario de Estado y ministro de relaciones exteriores temporario, Luiz Martins de Souza Dantas, emprendió una feroz campaña de difamación contra Barbosa y Zeballos. ${ }^{46} \mathrm{~A}$ las notas de periódicos germanófilos o de ciertos neutralistas que acusaban al senador de haber comprometido la política exterior del Brasil, se sumaba entre Souza Dantas y Barbosa un indigno escándalo por el pago de la misión - Barbosa decidió donar el dinero cobrado a un hospicio religioso de niños pobres y ancianos. Se le acusaba también de haber recibido al conspicuo "enemigo del Brasil" en el Hotel Plaza antes de encontrarse con al presidente argentino, sin mencionar su aceptación a comer en la residencia

43 Carta de Zeballos a Barbosa, Série Embaixada a Buenos Aires, Centro de Documentação, Arquivo Rui Barbosa, Fundação Casa de Rui Barbosa (348 documentos) [en adelante, “Archivo Barbosa”], RB-BA 1-1/6, 12-7-1916. La Protesta, 22 de julio de 1916, p. 1.

$44 \quad$ La Protesta, 22 de julio de 1916, p. 1.

45 Ibid.

46 No están claros los motivos profundos por los cuales Souza Dantas cambió repentinamente de actitud hacia Barbosa. Este diplomático había integrado la legación en Buenos Aires el año 1910 y se había mostrado activo en el proceso de embajadas de acercamiento generado a partir de la asunción de Roque Sáenz Peña. El año anterior al Centenario de la Independencia había viajado a la capital argentina y a Chile para gestionar el pacto $\mathrm{ABC}$. 
de Zeballos. En la conferencia en el palacio de La Prensa el embajador ya había festejado públicamente su reconciliación con Zeballos, así que frente a estas acusaciones no tuvo más que añadir a su defensa que lo había recibido el primer día por natural cordialidad entre caballeros ${ }^{47}$ Por su parte, Zeballos también justificó con detalle cada paso que efectuó para acercarse a su colega, según él, inspirado en la sincera admiración. ${ }^{48}$

En rigor, la pésima imagen pública de Zeballos en el Brasil contrastaba con los lazos de amistad que mantenía con varios intelectuales del país vecino. En 1912 fue el escritor, periodista y diplomático Manuel de Oliveira Lima quien intentó demostrar sin demasiado éxito que Zeballos no era enemigo de la nación brasilera. El jurista argentino había felicitado a su colega por la publicación de sus conferencias pronunciadas en la Sorbonne y, como consecuencia, Oliveira Lima envió una carta que fue publicada en La Prensa, y comentada en periódicos brasileros, donde manifestaba su deseo de que "se conheçam os verdadeiros sentimentos amigáveis do Sr. Zeballos para com o Brasil, porque pintam o estadista argentino como inimigo mortal dessa nação". ${ }^{49}$ Entre las numerosas cartas de felicitaciones que recibió Barbosa por su embajada se encontraba la de su querido amigo de Bahía y compadre (así lo llama a Barbosa), el abogado Thomas Guerreiro de Castro, quien destacaba:

muito estimei que em Buenos Aires houvesse conhecido de perto o nosso distincto Collega Dr. Estanislao Zeballos, que sempre nutrio para com o Brasil sentimentos os mais amistosos, embora jamais deixando de ser devotado e sincero amigo de seu Glorioso Paiz [...] Eu mantenho com elle as melhores relações de amizade, há seguramente, mais de 10 annos. ${ }^{50}$

Es decir, desde antes de que el argentino encabezara la campaña pro armamentos para lanzarse a una guerra contra el Brasil y previa también al incidente del telegrama número 9. Por otra parte, si bien Zeballos había sido crítico de Barbosa por su actuación en La Haya en 1907, dos años después publicó un artículo sobre la campaña presidencial en el que destacaba el valor de la campaña civilista de Barbosa contra el militarismo encarnado en el Mariscal Hermes da Fonseca a quien Zeballos consideraba que respondía al influjo de su vilipendiado Barón de Río Branco. ${ }^{51}$

47 Periódicos brasileros salieron en defensa de Barbosa. Una nota sin firma en A Rua acusaba a Souza Dantas de "desencavar cousas que já estavam esquecidas" porque "não tem o senso necessário para compreender o alcance e a necessidade da aproximação do Brasil com Argentina". A Rua, Semanário ilustrado. Río de Janeiro, 28 de agosto de 1916, p. 2. Luego de la conferencia del 14 de julio, Zeballos le envió una carta que exclamaba: "es usted un gigante en cuerpo pequeño", Archivo Barbosa, RB-BA 1-3-116.

49 Jornal do Commercio, Río de Janeiro, 1 de marzo de 1912, p. 2.

50 Bahía, 1 de agosto de 1916. Archivo Barbosa, RB-BA 1-4-238.

51 Estanislao Zeballos, "La futura presidencia del Brasil. Discurso de Ruy Barbosa". Revista de Derecho, Historia y Letras, Buenos Aires, J. Peuser, 1909, tomo XXXIV, pp. 471-474. 
En esta ocasión, la "redención" de Zeballos ante el Brasil fue facilitada por el periodista Sertorio de Castro quien presenció el primer encuentro entre los dos juristas en el Hotel Plaza, y luego efectuó una entrevista al argentino en su propia casa que describió en los términos más elogiosos. ${ }^{52}$ Con todo, pese a las explicaciones brindadas, diversos órganos de prensa, como la revista Careta, resucitaban incesantemente el incómodo prontuario del ex ministro argentino en sus relaciones con Brasil. A todo esto, vino a añadirse enseguida un nuevo escándalo. El senador Vitorino Monteiro y el diputado Gumercindo Ribas, ambos representantes de Rio Grande do Sul, clamaron en sendas cámaras porque Barbosa no le objetó a Zeballos el uso de la expresión "último caudillo" cuando se refirió públicamente al malogrado gaucho Pinhero Machado durante la presentación que hiciera de su invitado en el Instituto Popular de Conferencias. El jurista embajador y el jurista anfitrión, nuevamente, escribieron notas en su defensa. ${ }^{53}$

La acumulación de estos sinsabores casi provocó el arrepentimiento del senador Barbosa por haber aceptado semejante misión. Realmente, con esta campaña se ponía en riesgo, decía el ilustre intelectual, un trabajo arduo de construcción de confianza no sólo entre los dos gobiernos sino entre las dos sociedades. No obstante el revuelo suscitado en el campo político e intelectual brasilero, lo cierto es que la misión había conseguido gran éxito en la aproximación de los dos países y simultáneamente terminó siendo la última gran consagración internacional del "Águila de La Haya"..${ }^{54}$ Una nota del periódico carioca $A$ Rua resulta elocuente de la relevancia social que alcanzó la figura del jurista Barbosa por sobre la de la esfera militar en aquella hora: "Ha muitos dias, quase um mez (sic), que regressou do Prata a Embaixada que nos

52 El doctor Sertorio de Castro acompañó a la embajada Barbosa en representación de los periódicos A Noite, de Río de Janeiro, y O Estado de Sao Paulo. El 11 de julio el Círculo de la Prensa de Buenos Aires honró a los periodistas extranjeros que asistían a los festejos del Centenario. Pronunciaron discursos el doctor Alfredo Bastos en nombre de la Associação da Imprensa de Río de Janeiro y los señores Lemos Britos y Sertorio Castro en nombre del Estado de Sao Paulo. A Rua, Semanario Ilustrado, Río de Janeiro, 11 de julio de 1916, p. 1.

53 Estas polémicas fueron publicadas ese mismo año en español por Zeballos en un número de la revista de la cual era director, en este orden: "El señor Zeballos y su papel en las relaciones argentino-brasileñas" (notas de Sertorio de Castro comentadas al pie por la Dirección de la Redacción, es decir, Zeballos), cit.; "Intemperancia del senador Victorino Monteiro. Incidente en la sesión que celebró el Senado del Brasil el 7 de agosto de 1916"; "La defensa de Ruy Barbosa" (nota de Ruy Barbosa aparecida en portugués el 10 agosto de 1916); y por último, "Agresión del Ministro de Relaciones Exteriores", Revista de Derecho, Historia y Letras, Buenos Aires, Peuser, tomo LV, pp. 211-238.

54 Muchas notas que circulaban en periódicos de todo el Brasil se expresaban, por ejemplo, en este tono: "Ruy Barbosa, nosso embaixador nas festas comemorativas de centenário de Tucumam (sic), já regressou ao Brasil, voltando resplandecente de gloria, coberto de louvores como um conquistador de almas, no dizer de Zeballos. Sua palavra assombrosa maravilhou os povos da Argentina e pasmou o mundo inteiro", O Movimento, Villa de Contagem (Minas Gerais), 6 de agosto de 1916. 
representou no Centenario de Tucuman e até agora nenhum jornal procurou obter impressões do delegado militar..." ${ }^{55}$ El general Mendes de Moraes era, además, Director de material bélico del ejército brasilero. Con todo, es cierto que el carácter de prócer en vida de Barbosa no le alcanzará para torcer su mala suerte como candidato presidencial (véase Ilustración 1 e Ilustración 2).

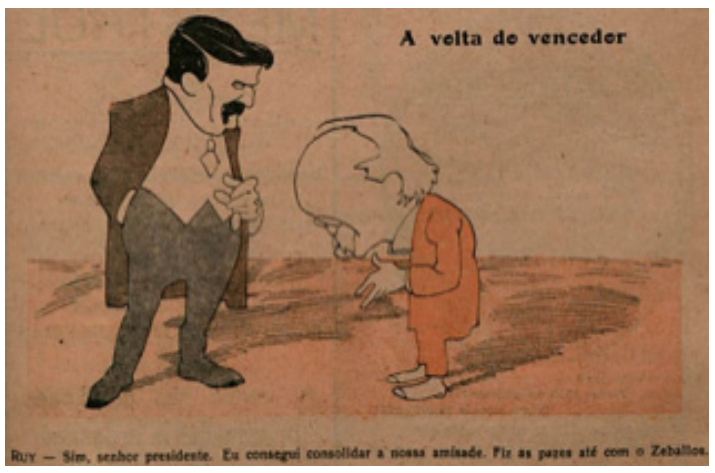

Ilustración 1. Careta, Río de Janeiro, 5 de agosto de 1916, p. 30.

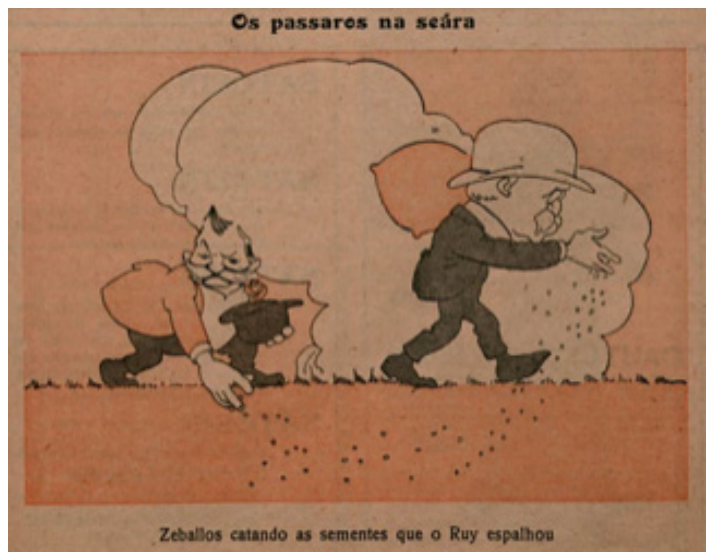

Ilustración 2. Careta, Río de Janeiro, 2 de septiembre de 1916, p. 32.

55 "O momento internacional. O general Mendes de Moraes diz o que pensou do povo argentino", A Rua, Río de Janeiro, 11 de agosto de 1916, p. 1. 


\section{VISITANTE ILUSTRE Y MEDIADOR SOCIOCULTURAL: EL VECTOR POPULAR}

Barbosa fue convocado a participar en los lugares y momentos más significativos dentro del programa de festejos. En la parada del 9 de julio (elogiada luego en su conferencia en La Prensa) las tropas argentinas compartieron columnas con las brasileñas y las uruguayas. Brasil decidió, como otra extraordinaria muestra de acercamiento, ascender su legación en Buenos Aires a la categoría de embajada (igual determinación adoptó España). El jurista recibió telegramas de alivio por haber resultado ileso en el atentado con arma de fuego cometido contra el presidente mientras estaba a su lado. El Consejo Nacional de Educación le extendió el programa junto con la invitación para que asistiera desde la tribuna oficial a la jura de la bandera y al desfile escolar en la Plaza Congreso el día 7 de julio. ${ }^{56}$ Desde Tucumán, donde se realizaba el congreso americano de ciencias sociales y se desplegaba un nutrido programa de festejos, le fueron enviadas cartas de salutaciones por parte del gobernador Ernesto Padilla y de la Universidad de esa provincia, por medio de su rector Juan B. Terán. El Centro de Estudiantes de Derecho saludaba al "defensor del sagrado principio de la igualdad de las naciones". 57 El Centro de Estudiantes de Derecho de la Universidad de Córdoba, donde dos años más tarde estallaría el movimiento reformista, saludaba por carta al sabio brasilero. Los estudiantes cordobeses encomendaron a José León Suárez, profesor de la Universidad de Buenos Aires y también reconocido jurista, que insistiera a Barbosa para que pronunciara una conferencia en aquella casa de estudios. Sin embargo, como señalamos anteriormente, Barbosa sólo se ausentó de Buenos Aires para visitar El Tigre. Asimismo, el Centro Católico de Estudiantes Universitarios y la Juventud Católica de Buenos Aires invitaron al brasilero a participar de la gran procesión de clausura del primer Congreso Eucarístico Nacional. Este impresionante despliegue en el espacio público fue aprovechado por el creciente movimiento católico para teñir con su impronta la efeméride patria. ${ }^{58}$

En un circuito repetido con frecuencia por los huéspedes ilustres, ${ }^{59}$ también recibió invitaciones para visitar las redacciones de La Nación y La Prensa, el Museo Mitre, el hipódromo, el Teatro Colón, el Museo Agrícola de la Sociedad Rural Argentina.$^{60}$ Ernesto Quesada le enseñó su famosa biblioteca y

56 Archivo Barbosa, RB-BA 1-1/6, 05-07-1916.

57 Archivo Barbosa, RB-BA 1-1/6, 02-07-1916.

58 Archivo Barbosa, RB-BA 1-4-229. La invitación formal fue cursada por la organización de la procesión del Congreso Eucarístico Nacional, firmada por su presidenta, señora Mercedes de Anchorena. Buenos Aires, 21 de julio de 1916, Archivo Barbosa, RB-BA 1-4-172.

59 Paula Bruno (coord.), op. cit.

60 Zeballos le informaba a Barbosa el programa de la visita que tendría lugar una vez finalizada 
le obsequió varios volúmenes, sin dejar de recordarle que su padre había sido un gran admirador suyo desde su viaje a Río de Janeiro. ${ }^{61}$ En los festejos de los Centenarios, no podía faltar el convite a alguna inauguración que escenificara el grado de civilización alcanzado por el país anfitrión, en este caso, el ministro de Obras Públicas lo invitaba a asistir al estreno de los edificios de los Institutos Nacionales de Bacteriología, Vacuna y Química. ${ }^{62}$ Los recorridos habituales de las visitas masculinas podían incluir también otro tipo de experiencias menos públicas. Barbosa conservó una curiosa carta de invitación de una tal Mercedes Bonaprart, dueña de una casa con "bonitas jóvenes argentinas" que había sido frecuentada, según ella, por otras altas personalidades brasileras en su paso por Buenos Aires. ${ }^{63}$

Más allá de los saludos, invitaciones y paseos que involucraban actores y espacios de sociabilidad de la élite política e intelectual, instituciones educativas, medios de prensa y el mundo diplomático, la presencia del jurista-embajador llegó a conmover la sensibilidad de amplias franjas de sectores medios y populares de la densa capilaridad social argentina. Las cartas que recibió mientras permaneció en Buenos Aires y que hoy forman parte del archivo personal de Barbosa nos da sugerentes pistas para indagar en lo que denominamos al comienzo como vector popular en la recepción de este tipo de embajadas y en particular permite analizar el lugar que ocupó en muchos sectores la presencia efímera, pero impactante de este sobresaliente mediador cultural en la capital porteña. Vale la pena examinar de cerca esta correspondencia, aun desconociendo si alguna de las misivas tuvo respuesta por parte del embajador o si éste complació a las solicitudes contenidas en muchas de ellas.

la conferencia en el Instituto de ese diario: "será invitado el Embajador y su comitiva a conocer el palacio de 'La Prensa' en funcionamiento, y a fin de evitarle molestias, esto tendrá lugar en el mismo salón por medio de una cinta cinematográfica". Buenos Aires, 14 de julio de 1916, Archivo Barbosa, RB-BA 1-3-115. Por su parte, la revista Careta informaba a sus lectores que las instalaciones de La Prensa poseían servicio médico para su personal, restaurantes, sala de armas, servicio gratuito de consulta jurídica y un laboratorio químico agrícola donde se analizaba en forma gratuita muestras de semillas y tierra enviadas por sus suscriptores. Careta, Río de Janeiro, 12 de agosto de 1916, p. 12. Buenos Aires, 20 de julio de 1916, Archivo Barbosa, RB-BA 1-4-173.

62 Buenos Aires, 4 de julio de 1916, Archivo Barbosa, RB-BA 1-1/6. El director era el Sr. Krause y cabe destacar que la sección de zoología médica había sido organizada por el médico brasilero Dr. Arthur Neiva. A Rua. Semanario Ilustrado, Río de Janeiro, 10 de julio de 1916, p. 10.

63 "Distinguido Señor: Me es muy grato ofrecerle mi domicilio Victoria 1860, donde espero tendré el honor de conocerle y hacer que conozca algunas argentinas muy bonitas que tengo. Puede Ud venir con toda confianza pues mi casa es muy seria y la mejor frecuentada de aquí, cuando estuvo el General Gliserio en Buenos Aires fue amigo mío y también el señor Guimaraes, en fin, muchos y muy distinguidos brasileros que han venido a la Argentina. Le ruego si es que se decidiera venir lo haga de tarde, de noche no se atiende a nadie. Firma: Mercedes Bonaprart”. Buenos Aires, 6 de julio de 1916, Archivo Barbosa, RB-BA 1-1/6. 
Antes y después de la famosa conferencia en la Facultad de Derecho, varias mujeres y algunos hombres de sectores medios y altos felicitaron a Barbosa y solicitaron un retrato autografiado, como era habitual ante estos visitantes. Muchos le enviaban la postal con su retrato para obtener en él su firma. También recibió cartas acompañadas de obsequios, muchas veces a cambio de ayuda pecuniaria por parte de miembros de sectores populares. Tal es el caso de la carta firmada por Benigno de Garay, "hijo de un viejo militar, al servicio del ejército brasileño en la guerra con el Paraguay, artista y pobre" ${ }^{64}$ Le obsequiaba una acuarela de la entrada a la dársena del crucero argentino "Buenos Aires", con la esperanza de que lo ayudase materialmente. ${ }^{65}$ Una carta escrita por Elisa R. de Mesina iba dirigida a la esposa de Barbosa, le obsequiaba un crucifijo a la vez que le pedía una ayuda monetaria para poder mantener a sus criaturas; en la misma tónica de la solicitud piadosa, otra mujer le enviaba un libro religioso ${ }^{66}$ Además de los pedidos de ayuda económica por parte de padres y madres de familia en la miseria, el embajador también recibió el ruego de algunos de estos padres para que intercediera ante el presidente Victorino de la Plaza con el fin de que les otorgara un empleo, uno de ellos hasta especificaba el salario mínimo que pretendía ganar. ${ }^{67}$

Otras misivas fueron escritas por inmigrantes brasileros o hijos de brasileros para congraciarse con el embajador y en algunos casos para solicitar su mediación para obtener beneficios concretos. En el primer grupo aparece la carta de salutación de Hermann Both, gerente del Banco Nación radicado en la ciudad de Ayacucho. Le informaba que era bahiano como él, con 47 años en la actualidad, había migrado a Argentina con sus padres a los nueve años y con mucho esfuerzo había alcanzado el puesto que lo honraba. Distinguía entre su patria brasilera y su patria adoptiva, donde había formado "una familia argentina-brasileña, honesta y numerosa que también es vínculo de confraternidad entre estas dos grandes naciones" ${ }^{68}$ Una experiencia similar contaba Joaquim Piaz, quien había migrado hacía 30 años a Buenos Aires y sus hijos ya eran argentinos. Celebraba el nuevo rumbo que adoptaba la política de su patria al enviar al ilustre Barbosa a la cabeza de la embajada, aunque

${ }_{64}$ Buenos Aires, 18 de julio de 1916, Archivo Barbosa, RB-BA 1-4-165.

65 Como señaláramos en la primera parte de este trabajo, la embajada extraordinaria presidida por Montes de Oca había arribado a Río de Janeiro en los cruceros "Buenos Aires" y "Patria" en noviembre de 1910. Los buques ocupaban un lugar privilegiado en los imaginarios nacionales de la época y por lo tanto desempeñaban un papel importante en el ritual de confraternidad.

66 Buenos Aires, 21 de julio de 1916, Archivo Barbosa, RB-BA 1-4-183.

67 Buenos Aires, 11 de julio de 1916, Archivo Barbosa, RB-BA 1-1/6. Otro caso es el de María Esther Cruz, profesora de piano, canto y solfeo que le pedía que intercediese ante el presidente argentino para que la ubicara en una cátedra en una Escuela Normal, pues no había tenido éxito en ello por falta de recomendación. 12 de julio de 1916, Archivo Barbosa, RBBA 1-1/6.

68 Ayacucho, 15 de julio de 1916, Archivo Barbosa, RB-BA 1-3-118. 
en forma agradecida y solemne le aclaraba: “jamás hemos sido víctimas de atropellos de clase alguna". ${ }^{69}$ Por su parte, con "saudade" por la patria de sus mayores, la señora Juana Núñez da Costa le expresaba a Barbosa su mayor admiración intelectual y le precisaba que "no era un extraño para mí, pues sus prestigios merecidamente adquiridos han traspasado en mucho los límites de la patria". ${ }^{70}$

En el segundo grupo, por ejemplo, se destaca una carta firmada por doce miembros de la colonia de brasileros residentes en la ciudad de Concordia, provincia de Entre Ríos, con el objetivo de solicitar su intermediación ante el gobierno de su país para que destinara un cónsul en esa ciudad y así poder proteger mejor los intereses de los compatriotas, en particular el de los trabajadores del Café Paulista, blanco predilecto de la violencia brasilófoba en los días del Centenario de $1910 .^{71}$ También se da la situación de brasileros que intentaban obtener un pasaje de regreso a Brasil, pedidos habituales a las legaciones, o bien casos como el de la señora Elviar Scotti Barbosa de Quiroga, vecina del barrio de Flores, que en su misiva le pedía ayuda económica evocando no solamente la patria común sino también "cierto grado de parentesco". Relataba en su carta la amarga historia de su inmigración, junto a sus padres, al país del Plata, empañada por promesas engañosas. ${ }^{72}$

Un trabajador del barrio de Barracas con clara conciencia de clase enviaba a Barbosa una carta respetuosa encabezada por el igualitario "señor" Barbosa. Sólo aspiraba a informarle que

las doctrinas promulgadas por Ud. han llegado no solamente a 'palacios' de magnates, si (sic) que también a 'ranchos' de modestos obreros. Tal es la fuerza y la claridad con que están vertidas (...) ¿por qué no decirlo? ¿acaso es pecado que un mísero lavorante (sic) se recree en elevar la vista hasta el astro que le fluye álitos (sic) vivificantes que le den gozoso consuelo? (...) hasta a conocimiento de los pobres ha llegado lo que usted ha dicho. ${ }^{73}$

No mencionaba ninguna filiación ideológica, pero si consideramos los elogios que también recibió su "internacionalismo pacifista" en el periódico anarquista La Protesta citado anteriormente, es probable que el discurso de Barbosa hubiese llegado a amplios sectores del movimiento obrero, en particular por su orientación aliadófila. Una vez más insistimos en la idea que vertebra este ensayo: el posicionamiento ideológico frente a la Gran Guerra suministró la fuerza para acrecentar, por oposición, el acercamiento entre las dos "naciones hermanas", tal la expresión repetida en esos años y llevada a su apoteosis durante el Centenario de 1916. 
La Guerra del Paraguay era un tópico presente en los discursos de confraternidad binacional, como quedó evidenciado en el acto del Círculo Militar donde el embajador brasilero pronunció uno de sus discursos. Muchas cartas evocaban esa memoria. Por ejemplo, el señor José Ignacio Garmendia, un declarado admirador de Barbosa, le enviaba una breve misiva en la que resaltaba el carácter de "dignos aliados" que tuvieron los dos países y encontraba el sentido de esa contienda en el "haber pulverizado una tiranía secular". ${ }^{74}$ Por otra parte, el vecino Alfredo Ferreyra, uruguayo residente en el barrio de Floresta, pedía a Barbosa que intercediera para lograr que Brasil y Argentina condonaran la deuda de guerra al Paraguay, como había hecho su país. Según este vecino, este gesto "haría (...) culminar la obra del acercamiento y armonía, la cual a juzgar por la reciente sanción de los Tratados A.B.C. ha de ser definitiva y perdurable...". ${ }^{75}$ Este sentimiento de solidaridad sudamericana ampliaba el objetivo de la misión de Barbosa. De hecho, si bien en una ocasión durante su estadía, el senador asistió a un banquete invitado por el embajador extraordinario chileno, sus discursos no aludieron en forma recurrente al Pacto $\mathrm{ABC}$, como podría suponerse. Si nos guiamos por las declaraciones del general Mendes de Moraes, agregado militar de la misión, no sólo "todas as patentes do Exercito argentino estão convencidas da necessidade de uma perfeita união dos povos sud-americanos, sobretudo agora quando a ninguém é dado prever as consequências da conflagração europeia", también aseguraba que "O 'ABC' é assim uma necessidade e tão compreendida, tão bem sentida pelo povo argentino, que este, nas suas manifestações de extraordinária imponência, cantava cadenciadamente nos seus desfiles: 'ABC'-'ABC'-“ABC'...”. ${ }^{76}$

Por último, otro artista que firmaba su carta como P. Martínez Isla, de la ciudad de La Plata, le obsequiaba a Barbosa un retrato suyo confeccionado sobre madera y, luego de aclarar el carácter original de su técnica, le pedía su colaboración para abrir una "Galería de las principales personalidades SudAmericanas" (sic). ${ }^{77}$ Estos indicios nos ilustran, en definitiva, sobre los modos populares de asimilar el momento latinoamericano a mediados de la década de 1910 .

\section{CONSIDERACIONES FINALES}

En las páginas precedentes, abordamos el viaje de la misión Barbosa a Buenos Aires en el Centenario de la Independencia argentina desde una perspectiva

74 Buenos Aires, 17 de julio de 1916, Archivo Barbosa, RB-BA, 1-1/6. Otro pintor le obsequió un cuadro de la batalla de Caseros.

75 Vélez Sarsfield, 18 de julio de 1916, Archivo Barbosa, RB-BA, 1-4-166.

$76 \quad$ A Rua... cit., 1916.

77 La Plata, s/f, 1916, Archivo Barbosa, RB-BA 1-4-230. 
interdisciplinaria. El desarrollo expuesto brinda aportes para una historia cultural de las relaciones internacionales entre Argentina y Brasil, y para una historia de los intelectuales centrada en la performance político-intelectual del "Águila de la Haya", a la vez que ofrece elementos para una historia cultural de los festejos de los Centenarios patrios sudamericanos.

En un comienzo, problematizamos la naturaleza polifacética de los integrantes de embajadas extraordinarias y misiones diplomáticas a comienzos de siglo Xx y avanzamos, luego, en la idea de que el viaje de Barbosa a Argentina representó el momento culminante de un ciclo de acercamiento político y social impulsado por ambos países luego de las tensiones producidas durante el gobierno de Figueroa Acorta.

A partir de la asunción de Roque Sáenz Peña a la presidencia se dio inicio a una tendencia de mutuo envío de misiones encabezadas por conspicuos funcionarios y buques de guerra con funciones de homenaje. Las primeras expresaron recíprocamente el desagravio a los símbolos nacionales del país vecino, luego de las manifestaciones populares ocurridas durante los meses de mayo, corolario de las incesantes campañas armamentistas. Tal sentido tuvieron las embajadas que asistieron a las asunciones presidenciales de Roque Sáenz Peña y del mariscal Hermes da Fonseca, respectivamente en octubre y noviembre de 1910. Paralelamente, avanzaban las negociaciones para limitar la adquisición de acorazados, por un lado, y ampliar los intercambios mercantiles entre los dos países, por el otro. En segundo lugar, la muerte del Barón de Río Branco en 1912 y la decisión de Lauro Müller de enviar como ministro al ex presidente Campos Salles (y, en retribución, el envío del ex presidente Roca al Brasil) no hizo más que consolidar esta tendencia. Tanto Barbosa como el periodista que lo acompañaba, Sertorio de Castro, señalaron que la misión de 1916 completaba un proceso iniciado con el viaje de la misión Campos Salles. Es comprensible que se vieran en ese espejo por la similar magnitud de los estadistas, por el carácter extraordinario de ambas embajadas, y por el recuerdo de la "reedición" en 1912 del "abrazo" de 1900, todavía presente no sólo en el mundo político, sino también, como testimonian los periódicos de la época, en amplios sectores de la sociedad. Sobre todo, puede entenderse tal consideración porque su promotor, el ministro Lauro Müller, era también quien avalaba la misión Barbosa. ${ }^{78}$ Sin embargo, hemos podido comprobar la

78 Según Sertorio de Castro, el "nombramiento [por parte del nuevo ministro Lauro Müller] del ex presidente Campos Salles para ministro extraordinario del Brasil en Buenos Aires, [fue] considerado como el punto inicial de la política saludable de verdadera aproximación entre los dos pueblos, culminada por la elección del señor Ruy Barbosa para embajador especial a las fiestas del Centenario de Tucumán", Sertorio de Castro, "El señor Zeballos y su papel en las relaciones brasileño-argentinas", Revista de Derecho, Historia y Letras. Buenos Aires, Peuser, tomo LV, 1916, pp. 211-224, p. 217, se trata de una reproducción parcial en español de dos artículos periodísticos, en este caso, "Impresiones del Río de la Plata. Buenos Aires. 
acogida que tuvieron las embajadas previas de confraternidad entre los dos países todavía bajo la gestión del Barón de Río Branco en Itamaraty, según sus protagonistas y también los testimonios recogidos en diversos órganos de prensa. Por lo tanto, es importante, a nuestro juicio, considerar que ese ciclo se inició con la visita de 1910 a Río de Janeiro por parte del presidente electo Roque Sáenz Peña y alcanzó su mayor despliegue político, intelectual y social con la misión Barbosa.

Con Barbosa en Buenos Aires, la figura del jurista internacionalista logró trascender los límites de una conmemoración nacional y terminó por consagrar su capital simbólico en el mundo entero. El afianzamiento retórico de un paradigma de paz y cooperación esbozado en oposición al trance de la guerra que devoraba a Europa contribuyó a este momento culminante del acercamiento entre Brasil y Argentina, y a la proyección internacional de Barbosa.

Una consecuencia inmediata del éxito de esta embajada fue la invitación cursada por instituciones académicas de Río de Janeiro y Sao Paulo al también jurista internacionalista José León Suárez para que impartiera una serie de conferencias sobre temas de su elección que favorecieran el conocimiento mutuo entre brasileros y argentinos. La misión León Suárez viajó a mediados de 1918 en representación de la Universidad de Buenos Aires y estaba integrada por el profesor y cuatro estudiantes. Al igual que en el caso de Barbosa, Suárez había mantenido contacto con diversos colegas del país vecino durante años y esa red fue decisiva para que se concretara la invitación proveniente de su maestro y amigo, el profesor Dr. Sá Vianna, quien era, al decir de Suarez, "uno de los más sólidos constructores de la actual amistad brasilero-argentina". ${ }^{79}$ Pese al carácter exclusivamente universitario de esta embajada, esta misión también tuvo impacto social y político en Brasil, más allá de la tribuna académica. Varios tópicos pacifistas esbozados por el argentino coincidían con los planteos de Barbosa en 1916. ${ }^{80}$

La entrada y el puerto. Visita de conjunto de la ciudad", aparecido el 4 de agosto de 1916 en el Estado de Sao Paulo.

79 José León Suárez, Diplomacia Universitaria Americana. Argentina en el Brasil. Ciclo de Conferencias. Derecho Internacional, Política Internacional, Historia Diplomática. Buenos Aires, Impr. Escoffier-Caracciolo, 1918, p. 11.

$80 \quad$ Ibid. Es sugerente el segundo título de esta obra: "La confraternidad Argentino-Brasileña en medio de la tragedia universal y en la aurora de un nuevo Derecho Internacional". De hecho, José León Suárez le había enviado a Barbosa una carta de admiración al día siguiente de su conferencia del 14 de julio, la encabezaba con un "Distinguido maestro". En ella anotaba: "me es muy agradable enviarle mi folletito 'La Guerra Europea y sus Consecuencias', contestación a la encuesta de la revista 'Nosotros' que publiqué en abril del año pasado. Si Ud. se digna ojear tan sólo la primera parte, (es muy corta), verá con cuánta razón debo estar satisfecho de las doctrinas que Ud. ha expresado". Como presidente del Círculo de Diplomáticos y Cónsules Universitarios, pasaba luego a trasmitirle siete números de la Revista Diplomática y Consular Argentina. Carta de José León Suárez a Ruy Barbosa, Buenos Aires, 15 de julio de 1916, Archivo Barbosa, RB-BA 1-3-119. 
La trascendencia social de los juristas internacionalistas en misión en aquellos años contorneó, a causa del contexto internacional de la Gran Guerra, una nueva figura pública, cuya voz hacía vibrar a amplios sectores sociales en la medida que actualizaba valores de confraternidad binacional, regional (ABC) y mundial. La atención del público sobre estas personalidades continuó en el contexto de los sinsabores experimentados durante la formación de la Sociedad de Naciones, que diera ocasión a un nuevo trance de rivalidad entre Argentina y Brasil en su competencia por la hegemonía moral sudamericana por sobre los gestos y discursos de solidaridad regional. Y fue poco después, durante la accidentada V Conferencia Panamericana en Santiago de Chile de 1923, que el péndulo volvió a inclinarse hacia el extremo de la desconfianza militar entre los dos países, pese a los esfuerzos del presidente chileno Arturo Alessandri por reflotar el ABC. La historia de los posteriores desencuentros entre Brasil y Argentina se escribiría, sin embargo, sobre capítulos cada vez más ricos de encuentros en el pasado, todavía palpitantes en la memoria de muchos.

\section{Bibliografía}

Bruno, Paula, "Martín García Mérou entre Brasil, Argentina y Estados Unidos. Observaciones para pensar el fin-de-siglo americano", en AA.VV, Gregorio Weinberg: escritos en su honor. Premio Gregorio Weinberg a la Investigación en Historia de la Educación, la Ciencia y la Cultura Latinoamericanas, Buenos Aires, Clacso, 2017, pp. 25-53.

_- Visitas culturales en la Argentina (1898-1936), Buenos Aires, Biblos, 2014.

Carvalho, Lyanna, "A cultura nas representações argentinas sobre o Brasil", Programa do pós-graduação em Letras e Linguística, Faculdade de Letras, Universidade Federal de Goiás, Goiânia, 2014.

Castro, Martín O., "Estanislao Zeballos: sensibilidad diletante, nacionalismo y estado, 1906-1912”, Anuario del Centro de Estudios Históricos 'Profesor Carlos S.A. Segreti', 2015.

Cisneros, Andrés y Carlos Escudé (eds.), "La diplomacia de los acorazados (1908-1914)", en ib. Historia General de las Relaciones Exteriores de la República Argentina. Ministerio de Relaciones Exteriores, tomo VII, cap. 37, $<\mathrm{http}: / /$ www.argentina-rree.com/7/7-053.htm $>$, consultado el 18 de noviembre de 2017.

Coelho de Souza Rodrigues, Joao, "Embaixadas originais: diplomacia, jornalismo e as relações Argentina-Brasil (1888-1935)”, Topoi (Río de J.). Río de Janeiro, vol. 18, no. 36, set-dic, 2017, pp. 537-562.

Compagnon, Olivier, América Latina y la Gran Guerra. El adiós a Europa (Argentina y Brasil, 1914-1939), Buenos Aires, Crítica, 2014.

Fernández, Sandra R. y Fernando Rubén Navarro (eds.), Scribere est agere. Estanislao Zeballos en la vorágine de la modernidad argentina. Rosario, Quinta Pata y Camino Ed., 2011. 
Fraga, Rosendo, Ramón J. Cárcano diplomático. La historia como instrumento de la diplomacia. Buenos Aires, CARI (Consejo Argentino para las Relaciones Internacionales), Serie Los Diplomáticos, núm. 18, 1999.

Garay, Cristián, "Las carreras armamentistas navales entre Argentina, Chile y Brasil (1891-1923), Historia Crítica, núm. 48, Bogotá, septiembre-diciembre, 2012, pp. 39-57.

Ministério de Educação e Cultura, Fundação Casa de Rui Barbosa, Obras completas de Rui Barbosa, vol. 43 (1916), tomo 1, Río de Janeiro, 1981.

Molina, Diego A., "Argentina y Brasil en tres acercamientos", Abehache, año 4, núm. 7, 20 sem., 2014, pp. 10-32.

Monteiro Real, Regina, Rui Barbosa em Buenos Aires. Cinquentenário da Embaixada a Buenos Aires, 1916-1966. Río de Janeiro, Fundação Casa Rui Barbosa, 1969.

Moraes Filho, Evaristo de, "A Embaixada a Buenos Aires", prefacio de Ministério de Educação e Cultura, Fundação Casa de Rui Barbosa, Obras completas de Rui Barbosa. Vol. 43 (1916), tomo 1, Río de Janeiro, 1981, IX-XCII [1978].

Ortemberg, Pablo, "El Centenario de la Independencia de 1916: tradiciones patrióticas, prácticas modernas e imágenes de progreso en el espejo de 1910", PolHis. Revista Bibliográfica del Programa Interuniversitario de Historia Política, año 9, núm. 18, julio-diciembre, 2016, pp. 103-143.

, "Los centenarios patrios en la construcción de alianzas y rivalidades internacionales: los festejos trasandinos de 1910, la estatua de O'Higgins y los bemoles peruanos", Jahrbuch für Geschichte Lateinamerikas/ Anuario de Historia de América Latina (JbLA), núm. 51, Viena, Colonia, Weimar, 2014, pp. 329-350.

Preuss, Ori, Transnational South America: experiences, ideas, anda identities, 1860s-1900s, Londres-New York, Routledge, 2016.

Scarfi, Juan Pablo, The Hidden History of International Law in the Americas: Empire and Legal Networks. New York, Oxford University Press, 2017.

Suárez, José León, Diplomacia Universitaria Americana. Argentina en el Brasil. Ciclo de Conferencias. Derecho Internacional, Politica Internacional, Historia Diplomática. Buenos Aires, Impr. Escoffier-Caracciolo, 1918.

Tato, María Inés, "A cien años de la Primera Guerra Mundial: una aproximación a su impacto en la Argentina", PolHis. Revista Bibliográfica del Programa Interuniversitario de Historia Política, Mar del Plata, 2015.

Waldmann Júnior, Ludolf, “As negociações para limitação de armamentos navais sulamericanos: o caso dos encouraçados no período entre as guerras mundiais". Interfaces da Ciência Política. I Semana de Pós-graduação em Ciência Política, Universidade Federal de São Carlos, s/f.

\section{Archivos consultados}

Archivo del Ministerio de Relaciones Exteriores y Culto de la República Argentina.

Archivo Histórico de la Cancillería de la República de Chile.

Arquivo Histórico del Itamaraty, Río de Janeiro.

Arquivo Rui Barbosa, Fundação Casa de Rui Barbosa, Río de Janeiro. 
Fuentes hemerográficas

A Rua, Río de Janeiro (1916).

A Rua, Semanario Ilustrado, Río de Janeiro (1916).

Careta, Río de Janeiro (1916).

El Día, Buenos Aires (1910).

Jornal do Brasil, Río de Janeiro (1910).

Jornal do Commercio, Río de Janeiro (1912).

La Nación, Buenos Aires (1910; 1915; 1916).

La Prensa, Buenos Aires (1910; 1915).

La Protesta, Buenos Aires (1916).

O Movimento, Villa de Contagem, Minas Gerais (1916).

O Paiz, Río de Janeiro (1910).

Revista de Derecho, Historia y Letras, Buenos Aires, J. Peuser (1909, tomo XXXIV; 1916, tomo LV). 